\title{
Cushioning the effect of Treasury Single Account (TSA) on the Liquidity Drive of Deposit Money Banks in Nigeria
}

\author{
Sowunmi E. Olatubosun \\ bosunsowunmi@gmail.com \\ Department of Banking and Finance
}

D.S.Adegbenro ICT Polytechnic, Itori-Ewekoro, Ogun State, Nigeria

\begin{abstract}
Deposit Money Banks in most African countries including Nigeria are already being properly normalized functionally as the official implementation of Treasury Single Account (TSA)in the country has brought them back from their initial functional abnormality exhibited through the collection and keeping of public sector funds.

Among various changes being put in place by the TSA include the transfer of the safekeeping responsibility and the protection of public fund from their purview by the country's apex bank (CBN),thereby leaving the Deposit Money Banks to serve solely as mere collection agents throughout the federation.

This appropriation of responsibility seems to be taking a negative toll on the liquidity status of the DMBs and thus, this study was conducted to determine the extent at which this said negative toll is imparting on the liquidity of the DMBs vis-à-vis measures towards ameliorating same in order to avoid going back to the dark days of bank failure. Descriptive and ex-post facto analysis style were utilized. We then used regression and correlation methods to analyze the secondary and time series statistical information obtained on the twenty four DMBs within the Country from the CBN bulletin of 2019. Our results disclosed that the policy implementation and its model has important impact on the liquidity of Deposit Money Banks and this translated further to a major impact on Credit to the Private Sector, Deposit Mobilization, Loans and Advances. The study in this wise recommended sure measures necessary for containing the earlier mentioned negative toll consequent upon TSA implementation on the liquidity of DMBs, which involves the necessity for DMBs to redouble their efforts on deposit mobilization from alternative sectors. This makes it possible for these DMBs to reduce their dependence on government fund for their operational activities. It went on to suggest future reconsolidation of the banking sector to permit for mergers, take over and outright acquisition among the DMBs, so the few stronger banks that will stay would possess the wherewithal to making wealth and jobs for the people, thereby improving and growing the Nigerian economy. The research ended with the position that the TSA policy be fully implemented and subsequently
\end{abstract}


sustained by the Nigerian government.

Keywords: Public Sector Funds, Treasury Single Account (TSA), Banks' Liquidity, Deposit Mobilization, Credit to the Private Sector, Loans and advances, Banking Sector, Consolidation, Merger, Take over, Acquisition.

\section{Introduction}

Deposit Money Banks in most African countries, including Nigeria, have neglected their main function of merely collecting agents for somewhat a functional abnormality of collecting and keeping of public funds within the past few decades.

The norm in an ideal situation is that the DMBs are responsible for the collection of public funds and then warehouse same at the apex bank of the country, being the official protector of the aforesaid fund. If any fund is to be collected and warehoused by the DMBs, such fund must belong to other sectors outside the public sector. This is why in a traditional economic setting; the banking sector is expectedly the engine of any nation's economy. This suggests that the economic standing of a nation depends on the stability of her banking industry. Since both public and private sector funds still circulate within the industry. Better put, any issue that affects the generality of the banks has a multiplier effect on the economy of such nation (Kanu, 2016).

The reverse is however the case in the present day Nigeria where, as a result of the aforesaid functional abnormality, the DMBs take custody of state funds that Ministries, Departments and Agencies (MDAs) generating government revenues deposit in their respective multiple accounts with the various branches of the commercial banks. We discovered in the course of our work that this resulted from the current practice of fragmented banking arrangement for revenue and payment transactions in the country. As a matter of fact, no government official can specifically at a particular time, make any specific pronouncement of government consolidated balance because of this multiplicity vis-à-vis fragmentations of bank accounts being kept and operated here and there. Many of these accounts are actually not known to government, as they are kept aside as "business accounts" between the bank officials and the so-called representatives of the MDAs. It thus becomes a free for all as both sides make huge gains from their shady exploits.

The deposit banks on their own part, make huge gains from the interest earned on the businesses they finance with part of the public funds deposited with them by MDAs who, in turn, paid into government account what they like, consequent upon this unchecked loopholes and unbroken proliferations as identified above. The resultant effect of the said atrocities translates to leakages of funds meant for government treasury, misapplication of public funds, high level corruptions and inability of a government to grasp her account balances at a glimpse; and hence, budgets could neither be adequately nor properly planned. Figures employed in these improperly planned budgets were vague and they were mostly based on surreal projections which in turn results in poor implementation. Quite unfortunately however, the chain of the "shady businesses" continue as the money banks who incidentally are the highest beneficiaries of these atrocities still go ahead to use this 
funds received from MDAs to provide loans with very high interest rates to the government under the guise of 'bail-out' in order for the government to be able to finance the nation's budget.

Resting on the assurances of the "free government fund" which often translates to huge but idle balances of state accounts in their books, money banks now care less about deposit mobilization from other sectors of the economy as they currently operated what we know as "arm chair banking".

All these, among different factors contributed to the scrawny growth of the Nigerian economy.

Being aware of the results of these multiple accounts vis-a-vis the surreal budget and erroneous planning among others, government directed all MDAs to close their accounts with commercial banks and get the balances therein across the specially designed account with the Central bank.

This new initiative codenamed TSA is said to be a unified structure of banking concern which is expected to facilitate consolidation of government accounts and as well enable the best utilization of state financial resources. It is through this consolidated bank account or set of bank accounts under the TSA canopy that the government transacts all its businesses involving receipts and payments; and gets a consolidated outlook of its cash position at any given time (Yusuf, 2016). Adeolu, 2016 posited further that "the maintenance of Treasury Single Account will facilitate and guarantee professional fund management by eliminating the possibility of idle funds usually left with the collecting agents (DMBs) under the previous arrangement. This is expected to enhance reconciliation of revenue assortment and payment. The foregoing reveals a major part of the changes being instituted by the TSA as we can see that the apex bank (CBN) presently takes over the custodian and warehousing of public funds, while the DMBs are left with their traditional function of collecting agents throughout the federation. This appropriation of responsibility seems to be taking a negative toll on the liquidity state of the DMBs and thus, this study was conducted to determine the extent at which this said negative toll is imparting on the liquidity of the DMBs vis-à-vis measures towards ameliorating same in order to avoid going back to the dark days of bank failure.

The question is- what is the impact of the TSA initiative on the liquidity level of DMBs in Nigeria? If any, then, we may wish to inquire whether or not this has taken any toll in their ability to extend credit facilities to both government and the private sector of the economy. Based on the above and considering the fact that the DMBs play a pivotal role in the stabilization of the economy through their support in relation to the continued existence of the private sector vis-à-vis their hitherto unshaken ability towards financing the micro-small and medium enterprises, the implementation of the TSA might probably represent an enormous impediment on the financial status of DMBs. A good example in this regard is the withdrawal of public sector funds totaling N2.2 trillion at the beginning of second quarter of 2015 from the DMBs (Adeolu, 2016). The impact of such amount of money on the DMBs could be better imagined. In addition, there is no gain saying that the movement of funds of revenue generating agencies and parastatals like the Nigerian National 
Petroleum Corporation (NNPC) out of the DMBs might equally represent a major impact on the liquidity status of DMBs and subsequently hamper the growth and development of the Nigerian economy. This growth set back would also manifest further with a rise at intervals of the lending rate of DMBs, which is as a result of monthly liquidity drop each time monthly allocation is withdrawn by the states.

It therefore becomes imperative to check the probable magnitude of this impact and to advocate measures towards ameliorating same in order to avoid going back to the dark days of bank failure as experienced in some parts of the nineteenth century.

\subsection{Research Questions}

Before propounding recommendations towards cushioning the perceived effects of the TSA initiative on DMBs, we shall attempt to provide answers to questions like:

1. Can Public Sector Fund (PSF) have any important impact on the liquidity status of DMBs?

2. Can the withdrawal of Public Sector Fund (PSF) from DMBs have any important impact on credit to the private sector?

3. Can the withdrawal of Public Sector Fund (PSF) from DMBs have any important impact on Loans and Advances to other sectors of the economy?

4. What practicable measures can the DMBs apply towards ameliorating the impact of the TSA initiative on their liquidity status?

\subsection{Objectives of the Study}

The main aim of this study is to examine the effect of TSA vis-à-vis practicable cushioning measures of such effects on the liquidity status of Deposit Money Banks (DMBs) in Nigeria. This we hope to achieve by determining the following:

1. To determine whether the withdrawal of Public Sector Fund (PSF) has any important effect on the liquidity status of DMBs

2. To determine whether the withdrawal of Public Sector Fund (PSF) from DMBs have any important effect on credit to the private sector

3. To determine whether the withdrawal of Public Sector Fund (PSF) from DMBs have any important impact on Loans and Advances to other sectors of the economy

4. To suggest practicable measures the DMBs may apply towards ameliorating the impact of the TSA initiative on their liquidity status.

\subsection{Research Hypothesis}

The Null hypotheses of the study were developed from the above stated objectives;

1. There is no important effect on the liquidity status of DMBs resulting from withdrawal of the Public Sector Fund (PSF)

2. There is no important effect on the credit to the private sector resulting from the withdrawal of Public Sector Fund (PSF) from DMBs

3. There is no important effect on Loans and Advances to other sectors of the economy resulting from the withdrawal of Public Sector Fund (PSF) from DMBs 


\subsection{Significance of the Study}

The result from this study would go a long way to serve as an eye opener for the promoters and Managers of DMBs to divert their attention from the free/idle fund of the Federal Government and thus intensify their efforts on Deposit mobilization from other sectors of the economy.

This research area would also help the public understand fully the impact of TSA, with specific relations to its merits and otherwise and how it may affect the financial players in the economy. It is also purposed to contribute some thesis in no little measure to literature for scholars and researchers interested in carrying out further research in related areas.

The paper is structured into five parts namely- Part 1: Introduction, Part 2: Literature Review, Part 3: Research Methodology, Part 4: Analysis and Implications of Findings, and lastly, Part 5: Summary of findings, Conclusion and Recommendation.

\section{Literature Review}

\subsection{Conceptual Framework}

One of the notable measures being undertaken by the Nigerian government to curb identified leakages in its treasury is the introduction of the Treasury Single Account (TSA) wherein public funds are being scooped into a common account managed centrally by the apex financial institution in Nigeria $(\mathrm{CBN})$. Treasury Single Account is said to be a unifying account that envelops all the government accounts with guaranteed transparency and assured accountability on the part of the public officers saddled with the management of such resources, (Adeolu 2016).

This was as a result of functional abnormality amongst the DMBs who, prior to 2015, took custody of state funds that Ministries, Departments and Agencies (MDAs) generating government revenues deposited in their respective multiple accounts with the various branches of the commercial banks instead of just collecting and remitting same to the CBN. This breeds the aforementioned leakages in public fund management within the country.

The TSA initiative by design is expected to ensure the remittal of money balances into one account with the aim of fostering integrity and obstruction of leakages publicly money management within the country. agency could be a public register underneath that all government revenues collected into one single account, typically maintained by the country's financial institution.

Giving a further definition of the TSA initiative, Zayol, Iorlaha and Nege (2017) opined that TSA could be a unified structure of government accounts saddled with the function of consolidation and ensuring the availability for optimum utilization of public fund. This and other definitions points at the precise aim of the initiative, that is to pool all government revenues into one account and guarantee optimum and widespread utilization for economic development. Sustaining the initiative is presumed to eliminate idle funds and improve the operational activities of different MDAs through the distribution of revenues.

Yusuf (2016) posits that TSA is a network of subsidiary accounts that are joined to the 
centralized account so that daily transactions made into the subsidiary accounts at intervals are thereafter transferred as closing balances to the central account at the closing of the operational activities of each day. Chukwu (2015) opined that a treasury single account is a unified structure of government banking accounts that provides a consolidated on-the-spot balance of at any point in time. This implies a total support of the initiative of the treasury single account which involves consolidating the government transactions including all its receipts and payments into a single and centrally controlled account.

In the opinion of Ighosewe and Ofor (2017), the initiative is a national policy with a singular aim of pooling all the revenues from all MDAs into one account managed by the apex bank. This connotes that TSA is an account managed by the apex bank (CBN) and not Deposit money Banks (DMBs).

This TSA initiative of the federal government is a modern way for effective management of the government's finances, banking and cash position, (CBN, 2015). It pools and unifies all government accounts through one treasury account.

Treasury Single Account (TSA) is one of the cash policies implemented by the Federal Government of Nigeria purposed to consolidate revenue from all ministries, departments and agencies (MDAs) in the country at intervals by technique of deposits into the DMBs from where such deposit can be traceable into one single account at the CBN.

This initiative was said to be empowered by Section 80 (1) of the 1999 Constitution as amended, which states that "all revenue or other money raised or received by the Federation ( in as much as such money is not tagged to any specifics) shall be paid into a specially formed account tagged Consolidated Revenue Fund of the Federation".

In line with the above, the IMF, (2010) highlighted three essential features of TSA and these are as listed hereunder:

First, the government banking arrangement got to be unified, in order for the ministry of Finance (or treasury) to possess an oversight responsibility over government cash flows in and out of these bank accounts.

Second, no government agency operates bank accounts outside the treasury single account arrangement.

Third, the consolidation of resources got to be comprehensive, and embody all funds including money and extra-budgetary.

The policy was introduced to reduce the proliferation of bank accounts operated by MDAs and to encourage transparency and professional uprightness among all organs of the government. Tayo (2015) claimed that the initiative is "The government's stand-alone revenue e-collection arrangement which is instituted for the purpose of automating revenue collections of ministries, departments and agencies (MDAs) into the government consolidated revenue fund (CRF) account at the CBN through the Remitta e-collection and other relevant electronic payment channels".

Adeolu (2016), said the adoption of the initiative will involve retail banking wherein DMBs perform as collecting agents and will also collect taxes/levies as well as involve in the disbursements /payment of salaries to civil servants, but are expected to operate a zero (O) balance in the affected revenue receipt account since all monies remaining in the said 
accounts are assumed transferred electronically to the Consolidated Revenue Account (CRA) at the close of every banking day, so that the banks are left with no public funds being used as capital in their day to day operations. As indicated in its objective, the TSA initiative is saddled with the responsibility of ensuring accountability of government revenue, enhance transparency and avoid misapplication of public funds. There is however few exceptions to the TSA initiative, going by the CBN bulletin for 2015, funds generated by joint venture partners with government like oil, mining, leases (OMLS) in the oil and gas industry need not be paid to the Consolidated Revenue Funds.

\subsubsection{Importance of the Treasury Single Account}

According to Adeolu (2016), the following are the importance of the operation of the treasury single account initiative in any economy.

i. The initiative primarily brings all government funds in bank accounts within the effective management and operational control of the treasury.

ii. It ensures and facilitates centralized, transparent and accountable management of state revenue.

iii. It facilitates effective cash management

iv. It ensures convenience of cash availability

v. The initiative promotes economical management of domestic borrowings at affordable rate.

vi. TSA permits optimum investment of idle cash.

vii. Its implementation blocks leakages in revenue management.

viii. The initiative establishes a cost-effective collections and disbursement mechanism for state funds.

ix. The TSA improves liquidity reserve

$\mathrm{x}$. It eliminates operational inability and costs associated with maintaining multiple accounts with multiple banks.

\subsubsection{Treasury Single Account and liquidity issue of DMBs in Nigeria}

The Federal government of Nigeria in 2015 transferred the custodian of government revenue of all MDAs from DMBs to the apex bank of the country, Central Bank of Nigeria upon at the inception of the Treasury Single Account (TSA) initiative. This, according to literature added to the stress of liquidity crunch being experienced by DMBs in the banking industry. It would be recalled that prior to year 2015, commercial banks have been the custodians of government funds (Kanu, 2016), and have since enjoyed the free flow of funds from MDAs.

This initiative appeared unfavourable to the DMBs to the extent that it greatly shakes the liquidity pillars of the banks and in turn affects their profitability. According to Ndubuaku, Ohaegbu and Nina (2017), they noted that the TSA generated much fear in the banking industry even before its implementation. This includes the extant Monetary Policy of the CBN putting the approved rates at 13\% (Monetary Policy Rate-MPR), 20\% (Cash Reserve Ratio-CRR) and 75\% (private and public sector deposits) respectively, the implementation 
of the TSA initiative would not be favourable to banks. Worthy of note in this regard is the usual monthly experience of the DMBs each time the monthly federal allocation is released, the banking system is usually awash with good liquidity status, which subsequently results in an instant crunch and as soon as the owners of the fund withdraws it. This as well translates to an increase in interbank rates. This crisis becomes more prominent whenever a high revenue generating parastatals like the NNPC, customs, FIRS among others move out of commercial banks (Kanu, 2016). It is without doubt that commercial banks will be tremendously affected by the Treasury Single Account policy. Its implementation would cause insufficiency of available cash in the banking system, resulting in a surge in money market rates during the period as banks source for funds to cover their poor liquidity positions. Kanu went further by drawing a conclusion that the Nigerian banking industry would be generally affected by this policy regarding deposits and funding cost structure.

The TSA policy has come to stay! It is a way of compelling the banks to re-strategize and focus on the funds of the real sector of the economy, rather than spending much on Federal Government projects, Oil \& Gas Transactions, Forex dealings, etc. Managements of banks should understand the aim of establishing banks. The Government is not the only customers banks have. The Government is not only customer banks have. The issue of banks chasing government money at the expense of other clients especially in the sector of the economy is questionable and should be seriously discouraged.

Tari, Pwafeyeno, \& Minnessi, 2016) quoted the Guardian of August 16, 2015 as saying that the net liquidity position of the DMBs would definite be reduced upon the full implementation of TSA and the multiplier effect of this shall tell their credit creation ability and hence low profitability. This is very similar to the view expressed by Iyer, Peydro,da Rocha-Lopes, and Schoar in 2014. According to them, full implementation of TSA will not only affect the liquidity of banks, it will also affect their profit level. In this regard, Uarame and Chijioke, (2015) submitted that the 2.2 trillion that left the deposit money banks in 2015 as a result of TSA grossly affect the whole economy and not only the banking sector.

This could be the reason why some scholars argued that full implantation of TSA did not take into consideration other vital sectors of the economy directly or indirectly connected to the banking sector, and these vital sectors could improve the living standard of people. As a matter of fact, those commercial banks that may fail to operate based on the core banking functions for which they were licensed must be advised to close shop. This will however cause heavy downsizing of staff, thereby increasing the unemployment rate in the country. On the contrary, Ndubuaku, Ohaegbu and Nina (2017) submitted that the full implementation of the TSA will not be hurting banks per se. It will only curb the potential failures in the industry who have otherwise refused and jettisoned the tenets of banking as it is done everywhere. It is an opportunity for real banks to refocus on the original purposes for which they were set up to collect depositors' funds, keep them safe; engage in intermediation to create wealth and jobs for the economy and by so doing, earn a profit for themselves. 


\subsection{Theoretical framework}

The study into the effect of the Treasury Single Account initiative on the liquidity of banks is anchored the following theories among others: Incremental Theory, Liquidity management theory and Stakeholders' theory. We shall take a little time on each of the theories respectively.

\subsubsection{Incremental Theory}

The complex nature of human beings is grossly and worrisomely engulfed by various, wild drawbacks. Quite unfortunately, the resources as well as the analytical skills at their disposal which are necessary to tackle these wild but complex drawbacks are relatively very scarce and at times not available. This is the premise upon which the incremental theory is established. In their submission, Ogbonna and Amuji (2018) stressed that instead of getting involved in the concern to get solution to these problems, people only disagree at every available opportunity making it almost impossible to get satisfactory solutions to the identified problems.

It was thus suggested by Lindblom, (1959) that the use of "bounded rationality" rather than solving the problems only in an analytical manner should be employed through the appropriate government agency. Incidentally, the whole essence of the TSA initiative is in tandem with the main objective of bounded-reality which is a united framework through which the complexities of human involvements in unpatriotic acts such as corruption could be curtailed.

We should recall that the essence of the TSA initiative is to ensure transparency, accountability and probity among public office holders, and also, the redistribution of government revenue. This incremental model of public policy aligns perfectly with the TSA policy as it is specifically aimed at increasing government revenue and as well, a reliable tool for solving manifold problems of social policy such as corruption, lack of accountability, leakages which have undermined government efforts to fulfill the social contract in delivering public goods to the people. Critics of this theory however claimed that it is not oriented. In the words of Ogbonna and Amuji (2018), some even went further to identify a loop-hole in the implementation of TSA in Nigeria as it did not put into consideration firms in the banking industry whose working capital is largely attached to public funds.

\subsubsection{Liquidity management theory}

According to Ross 2016, liquidity optimization which involves avoiding losses around deposits is though a paramount objective of the Liquidity management theory, but it is only one aspect of the theory. Another major aspect of the theory deals with the management of internal capital investing and lending to subsidiaries. This aspect extends to the management of working capital, and minimization of idle cash with the aim of optimizing the commercial cash flows achieved through netting and cash concentration. Above all, liquidity theory becomes relevant to this research work as it prioritizes the avoidance of 
liquidity problems and creating the "cash is kinge culture for smooth operations and suppliers relationship (Premchad, 1996). Through this feat, it informs the DMBs of the need for deposit mobilization drive outside the public sector.

\subsubsection{Stakeholders' theory}

The purpose of an organization is to manage its Stakeholders in their areas of interest, needs, and viewpoints. Stakeholders in an organization are people who have identifiable relationships with the organization. Stakeholder management according to Friedman and Miles, 2006 is a major area of business concern necessary to be fulfilled in an organization. Stakeholders' theory authored by Freeman came into existence in 1984 and it centers on any individuals or groups who can affect the decision of an organization. These set of people are progressively minded and would in no measure condone any atrocity by the evil minded civil servants and political leaders in the country. This is particularly the reason for its relevance to the implementation of Treasury Single Account (TSA) in that the existence of TSA coincidentally was as a result of the influence of the patriotic stakeholders who felt concerned about the achievement of the organization objectives. This calls for the government attention towards introduction of the TSA initiative.

\subsection{Empirical Review}

Most authors that worked on varieties of related topics since 2015 when the federal government brought the TSA initiative into the economic policy of Nigeria centered their searchlights on topics that has to do with whether the profitability of firms in the banking industry could be affected; whether or not there were effects and or impacts of the TSA policy implementation on banks' performance, liquidity; and so on. Of course their findings brought various conclusions, but most notable of all were the fact that there was no much difference in the bank's overall performance; and that the implementation of the TSA vis-àvis the little effect it has on banks' performance in general brought with it an appropriation of functional responsibility to the leadership of the DMBs in particular, who hitherto relied only on Federal government funds at the expense of other sectors of the economy which are grossly under-banked.

The Central Bank of Nigeria (CBN) however deviated a little from the above and some other empirical submissions as they discovered in 2015 through their study on "the impact of Treasury Single Account on the Performance of the Banking Sector in Nigeria" that this newly introduced policy may not favour the commercial banks in terms of Credit to the other sectors outside the government purview, Deposit Drive, and Loans/Salary Advances. This finding was made through a regression analyzed time series data gathered from their annual bulletins. The study unexpectedly did not focus on the indicators of profitability in particular as required, and as such could not be taken as absolute.

In Onuorah (2016), the author in his study titled "Impact of Treasury Single Account (TSA) on the performance of banks in Nigeria" used multivariate data obtained from 2 commercial banks namely: Diamond and First Banks. He employed the use of multivariate analysis model to determine the statistical figures and discovered that there was no significant 
difference between the period before and after the introduction of the TSA policy on the performance of banks in Nigeria The two banks used as the sample size fell on the ratio 2:24 or 1:12 when the total number of banks in Nigeria is considered. This is too small a ratio to generalize the effect of TSA on the profitability of banks in Nigeria, and it therefore calls for a larger ratio for proper generalization.

A similar finding was reported by Ocheni (2016) where he undertook a study on the effect of TSA on commercial banks' performance in Nigeria and discovered that implementation of TSA has no significant impact on their performance. He used the least square method of analysis on a time series data that covered the period of 2012 to 2016 to make his findings, but the result cannot however be said to be perfect as the study was conducted on few randomly selected commercial banks.

Conversely, Kanu, (2016) conducted a study on the impact of TSA implementation on the liquidity of banks in Nigeria using 10 Deposit Money Banks (DBMs) and his study covered years 2010-2015. He conducted the analysis with the use of t-test and regression and the findings revealed that TSA has a negative impact on the liquidity of banks in Nigeria. A point of concern to researchers like myself is that, the study only covered the period before the advent of TSA and up till year 2015, whence it was first implemented. We quest to know what happened thereafter.

Similarly, Ofor (2017) in his study titled "The impact of TSA on the liquidity of banks in Nigeria" used questionnaires to elicit the needed data from ten (10) Deposit Money Banks (DMBs) and the data was analyzed via Chi-square. He got a negative relationship in his findings. Another study was conducted by Ogbonna and Amuji (2018) on the effects of the Treasury Single Account (TSA) on Bank performance in Nigeria. They used Ordinary Least Square (OLS) to analyze the data gathered through questionnaires, and discovered the existence of a negative but significant relationship between TSA and banks' profitability. The usage of questionnaires to determine the extent at which TSA has affected banks' profitability; and the number of banks in a single state may be too small to generalize what the whole banking sector is experiencing especially in this TSA dispensation, hence there is a need for further study of this nature to close this gap.

Further to the above, and considering the identified gaps as indicated, it might be difficult to ascertain if truly TSA has negative influence on liquidity, profitability and general performance of banks in Nigeria.

This gap therefore, necessitates this present study which aims examine the effect of TSA vis-à-vis practicable cushioning measures of such effects on the liquidity status of Deposit Money Banks (DMBs) in Nigeria and we have decided to add three years post- (TSA) implementation to the period covered (2003-2018), in our quest to know what happens after the introduction of the TSA policy initiative..

\section{Research Methodology}

This study utilized descriptive and ex-post facto analysis style. The population of the study comprises the twenty four commercial banks in Nigeria. We obtained the time series data used from the CBN statistical Bulletin; and the said data covering years 2003-2018 were 
analyzed using Regression and correlation analyses.

\section{Model Specification}

1. $D P M=f(P S F)$

2. $C P S=f(P S F)$

3. $L A D=f(P S F)$

Where:

$\mathrm{DPM}=$ Deposit Mobilisation; PSF $=$ Public Sector Fundt CPS $=$ Credit to the Private Sector; LAD =Loans and Advances

The above Model for the purpose of Analysis could be re-written as:

1. $D P M=\alpha+\beta(P S F)+\varepsilon$

2. $C P S=\alpha+\beta(P S F)+\varepsilon$

3. $L A D=\alpha+\beta(P S F)+\varepsilon$

Where:

$\alpha=$ Intercept; $\beta=$ Coefficient of the explanatory variable (slope); $€=$ Represents the error term in the model

\section{Data Presentation, Analysis and Interpretation of Results}

Here, we present data analysis, interpretation and discussion of our findings within the course of the study.

The study is purposed to see the effect of treasury single account initiative of the federal government on the liquidity status of deposit money banks in Nigeria with the mind of suggesting practicable cushioning factors necessary for ameliorating same.

Regression and correlation analysis were employed to ascertain the relationship between TSA [represented here by Public Sector Fund (PSF)] and liquidity details of the Commercial Banks in Nigeria [represented here through respective banks' performance on Deposit Mobilization (DPM), Credit advancement to the Private Sector (CPS) and Loans and Advances (LAD)].

\subsection{Test of hypothesis:}

\section{Hypothesis 1:}

There is no important effect on the liquidity status of DMBs resulting from withdrawal of the Public Sector Fund (PSF) 
Table 1: Regression, Correlation analysis between Public Sector Fund and Deposit Mobilization

\begin{tabular}{|c|c|c|c|c|c|}
\hline \multirow[b]{2}{*}{ Model } & \multicolumn{2}{|c|}{ Unstandardized Coefficients } & \multirow{2}{*}{$\begin{array}{l}\text { Standardized Coefficients } \\
\text { Beta }\end{array}$} & \multirow[b]{2}{*}{$t$} & \multirow[b]{2}{*}{ Sig. } \\
\hline & $\boldsymbol{B}$ & Std.Error & & & \\
\hline $\begin{array}{l}1 \text { (Constant) } \\
\quad P S F\left(N^{\prime} b\right)\end{array}$ & $\begin{array}{l}2995.263 \\
2.881\end{array}$ & $\begin{array}{l}1072.146 \\
1.239\end{array}$ & .528 & $\begin{array}{l}2.794 \\
2.325\end{array}$ & $\begin{array}{l}.014 \\
.036\end{array}$ \\
\hline
\end{tabular}

a. Dependent Variable: Deposit Mobilization (N'b)

Source: Research Finding 2019

Regression Model

$D P M=2995.263+2.881$ (PSF)

A cursory look at the regression model indicates a positive relationship between the Public Sector Fund (PSF) and Deposit Mobilization (DPM). An increase of One Naira in PSF would lead to a proportionate increase of 2.881 Naira in DPM and vice versa. The correlation coefficient of 52.8 percent indicates a strong positive relationship between Public Sector Fund (PSF) and Deposit Mobilization (DPM).

The $\mathrm{P}$ value obtained, (0.036) was less than 0.05 . This means that the $\mathrm{P}$ value is statistically significant at $5 \%$ level; and since tcal (2.325) is outside our acceptance region (+/- 1.96), we therefore reject the null hypothesis and uphold the alternative hypothesis. That is, there is a significant effect of Public Sector Fund (PSF) on Deposit Mobilization (DPM).

This implies that the TSA policy which seeks to withdraw Public Sector Fund (PSF) from the commercial banks would translate to a significant reduction in the liquidity status (Deposit Mobilization) of the DMBs. This is in agreement with Kanu, 2016.

\section{Hypothesis 2:}

There is no important effect on the credit to the private sector resulting from the withdrawal of Public Sector Fund (PSF) from DMBs

Table 2: Showing Regression, Correlation analysis between Public Sector Fund (PSF) and Credit to the Private sector (CPS)

\begin{tabular}{|c|c|c|c|c|c|c|}
\hline \multicolumn{7}{|c|}{ Coefficients $^{\mathrm{a}}$} \\
\hline \multirow{2}{*}{\multicolumn{2}{|c|}{ Model }} & \multicolumn{2}{|c|}{ Unstandardized Coefficients } & \multirow{2}{*}{$\begin{array}{l}\text { Standardized Coefficients } \\
\text { Beta }\end{array}$} & \multirow[b]{2}{*}{$t$} & \multirow[b]{2}{*}{ Sig. } \\
\hline & & $\boldsymbol{B}$ & Std.Error & & & \\
\hline 1 & $\begin{array}{l}\text { (Constant) } \\
P S F(N ' b)\end{array}$ & $\begin{array}{l}4580.233 \\
5.317\end{array}$ & $\begin{array}{l}1671.147 \\
1.931\end{array}$ & .593 & $\begin{array}{l}2.741 \\
2.753\end{array}$ & $\begin{array}{l}.016 \\
.016\end{array}$ \\
\hline
\end{tabular}

a. Dependent Variable: Credit for Private Sector Development (N'b)

Source: Research Finding 2019

Regression Model

$C P S=4580.233+5.317(P S F)$ 
A cursory look at the regression model indicates a positive relationship between the Public Sector Fund (PSF) and Credit to the Private Sector (CPS). An increase of One Naira in PSF would lead to a proportionate increase of 5.317 Naira in CPS and vice versa.

The correlation coefficient of 59.3 percent indicates a strong positive relationship between Public Sector Fund (PSF) and Credit to the Private Sector (CPS).

The $\mathrm{P}$ value obtained, (0.016) was less 0.05 . This means that the $\mathrm{P}$ value is statistically significant at 5\% level; and since tcal (2.753) is outside our acceptance region (+/- 1.96), we therefore reject the null hypothesis and uphold the alternative hypothesis. That is, there is a significant effect of PSF on Credit advancement to the private sector.

This implies that the TSA policy which seeks to withdraw PSF from the Commercial banks would translate to a significant reduction in the Credit being advanced to the Private Sector. This is also in agreement with Kanu, 2016.

\section{Hypothesis 3:}

There is no important effect on Loans and Advances to other sectors of the economy resulting from the withdrawal of Public Sector Fund (PSF) from DMBs

Table 3: Showing Regression, Correlation analysis between Public Sector Fund (PSF) and Loans and Advances (LAD)

Coefficients $^{\mathrm{a}}$

\begin{tabular}{|c|c|c|c|c|c|c|}
\hline \multirow{2}{*}{\multicolumn{2}{|c|}{ Model }} & \multicolumn{2}{|c|}{ Unstandardized Coefficients } & \multirow{2}{*}{$\begin{array}{l}\text { Standardized Coefficients } \\
\text { Beta }\end{array}$} & \multirow[b]{2}{*}{$t$} & \multirow[b]{2}{*}{ Sig. } \\
\hline & & $B$ & Std.Error & & & \\
\hline & $\begin{array}{l}\text { (Constant) } \\
\text { PSF (N'b) }\end{array}$ & $\begin{array}{l}4150.694 \\
2.980\end{array}$ & $\begin{array}{l}1203.429 \\
1.391\end{array}$ & .497 & $\begin{array}{l}3.449 \\
2.143\end{array}$ & $\begin{array}{l}.004 \\
.050\end{array}$ \\
\hline
\end{tabular}

a. Dependent Variable: Loans/Salary Advances (N'b)

Source: Research Finding 2019

Regression Model

$L A D=4150.694+2.980(P S F)$

A cursory look at the regression model indicates a positive relationship between the Public Sector Fund (PSF) and Loans and Advances (LAD). An increase of One Naira in PSF would lead to a proportionate increase of 2.980 Naira in (LAD) and vice versa. The correlation coefficient of 49.7 (approx. 50 percent) indicates a moderate and positive relationship between Public Sector Fund (PSF) and Loans and Advances (LAD).

The $\mathrm{P}$ value obtained, (0.050), though equal to 0.05 , but since tcal (2.143) is outside our acceptance region $(+/-1.96)$ it still maintains that the $\mathrm{P}$ value is statistically significant at 5\% level. We therefore reject the null hypothesis as we uphold the alternative hypothesis. That is, there is significant impact of Public Sector Fund (PSF) on Loans and Advances (LAD).

This implies that the TSA policy which seeks to withdraw Public Sector Fund (PSF) from the Commercial banks would translate to a significant reduction in the volume of Loans and Advances (LAD) extended to other sectors of the economy. 


\section{Summary of Findings, Conclusion and Recommendations \\ 5.1 Summary of Findings:}

So far, our research work and our findings through the result analysis as seen in the last section of this work has provided adequate and satisfactory answers to our queries as indicated earlier within the study. Firstly, we found out that the withdrawal of the Public Sector Fund (PSF) have significant effect on deposit volume (liquidity status) of DMBs. We equally confirmed that the withdrawal of the Public Sector Fund (PSF) affects greatly the DMBs' degree of credit being extended to the private sector, as well as the amount of Loans and Advances being extended to the other sectors of the economy. These findings are in conformity with the findings of Kanu (2016) where he posited that the implementation of the TSA initiative by the federal government of Nigeria has significant effect on the liquidity status of DMBs; that eventually translated to the areas focused in our study. In the same vein, Yusuf (2016) posited that, the implementation of TSA is capable of blocking leakages; and making positive changes in the transparency and reliability level of public finance management. In summary therefore:

i. there's a significant relationship between the TSA initiative and the Liquidity status of Banks.

ii. The implementation of initiative has negatively impacted on the Liquidity status of Banks, thereby causing some cash crunch which resulted from the eliminated float within the banking sector.

iii. The crunch through the implementation of TSA and withdrawal of idle-funds from the Banks has created a surge within the inter-bank lending rate.

iv. The drop in the liquidity level of Banks has reduced the value and volume of credit to its customers and this in turn has negatively impacted on economic activities in the country.

v. The TSA has effectively blocked loopholes and curbed corruption since its implementation has made it possible for government to have effective management of its money resources.

The foregoing among others are in consonance with the position of Rossi (2016) of the Deutsche Bank that, overnight deposits that do not constitute part of operational balances are not beneficial to the Liquidity of the Banking Institutions as banks now hold zerobalance accounts for all government agencies.

\subsection{Conclusion}

Cushioning the effect of Treasury Single Account (TSA) on the Liquidity status of Deposit Money Banks in Nigeria depends solely on the extent/magnitude of such effects of the initiative as adopted and the policy of the apex bank of the country (CBN). The study reveals that the implementation of TSA has greatly affected the Liquidity level of Banks and this is usually due to the great level of reliance of Banks on the public funds which were hitherto left idle amidst the DMBs' operational balances. Such funds were mostly extended as credit to their customers at no cost to the commercial banks. More so, it had been discovered that in line with the objectives of the study, the implementation of the TSA 
policy initiative effectively achieved its main aim of removing public funds within the commercial banks and this considerably affected the liquidity level of DMBs as we saw in the volume of Deposit Mobilization, reduction in extension of Credit to the private Sector as well as Loans and Advances to the other sectors of the economy.

All these and many more in this regard form the basis of our concern as mirrored in the suggestions/recommendations indicated hereunder.

\subsection{Suggestions of Practicable Cushioning measures and Recommendation}

Further to the findings of this study and in line with the our objectives as outlined earlier in the work, it's pertinent to advocate practicable measures that may be applied by the commercial Banks in country so as to cushion the implications of the implementation of the TSA policy, which would in turn improve their liquidity base and therefore, they can efficiently face the core functions for which they were licensed.

First, Bank managers are expected to be proactive in their decision making; they have to keep up wise, lasting customer relationships that may engender an increase in their customer base. This is a sure way to improve their liquidity base.

Also, DMBs should endeavour to as much as possible avoid arm chair activities by meeting their customers wherever they are and avoid over-reliance on government funds, rather scramble for funds from other sectors of the economy. Additionally, rural banking has to be compelled to be rigorously undertaken to mobilise funds from the un-banked among rural dwellers. Moreover, Banks have to deliver credit facilities, investment and saving opportunities to the populace, and encourage people denied of such access as this may improve their liquidity base and result to a reliable banking sector within the country.

Lastly, the Central bank should endeavour to maintain a versatile minimum financial policy rate (MPR) or discount rate in order to enable Banks take advantage of the alternative measures of meeting the unexpected withdrawal and lending demands within the economy.

Generally and based on the foregoing, the study concludes by making the following recommendations:

a. That the Central Bank should think outside the box and take certain proactive measures at ensuring that adequate measures capable of correcting all anomalies leading to negative impact of the policy both on the banking sector and the economy at large are put in place.

CBN have to be compelled to transcend the principles and place in situ measures to correct any lapses of negative impact of the policy each on the banking sector and then the economy at immense.

b. That CBN should consider a minor modification to the TSA policy initiative in that the model may accept the DMBs as the custodian of the main account as this will provide a succor for their Liquidity problems and as well reduce the inter-bank call rate surge being experienced among the banks from time to time.

c. That a sure alternative measure to ensure total compliance to the policy is by putting in place a compliance desk at the Federal Ministry of Finance to facilitate reconciliation between MDAs, Banks, collection agent, payers and the treasury; this would go a long way 
at eradicating corruption, as well as improving accountability and transparency within its stakeholders.

d. That the CBN should recognize the need for the formation of mega banks that can meet the liquidity needs of teeming Nigerians and as such, call for another round of consolidation to open up for mergers and outright acquisition among the DMBs in order to bring this need to reality.

e. With the availability of the Mega Banks as mentioned above, DMBs should be encouraged to give credit facilities, investment and saving opportunities to people who are denied as this will not only improve the economy, but would also result to a sustainable banking sector in the country.

f. In a bid to overcome their overdependence on government fund for operational activities must be discouraged, managers of DMBs should work out modalities that will foster the embracement of the core values of the banking system and rise up to their primary responsibility of collecting depositors' funds, keep them safe and engage in intermediation to create wealth and jobs for the teeming population in Nigeria.

\section{References}

Adeolu, I. (2015). Understanding the Treasury Single Account (TSA) System-Things you got to acknowledge. Business and Economy Review, Market Development geographic point of the controller General of the Federation, Abuja.

Central Bank of African country (2015). Revised pointers for Compliance with Treasury Single Account (TSA) by the govt in African country.

Chukwu, I.K. (2015). can Treasury Single Account (TSA) add African country. Retrieved from Vanguard Editorial Newspaper.

Freeman, R. (1984). Strategic Management: A neutral Approach. Pitman, Boston, MA.

Friedman, A. and Miles, S. (2006). Stakeholders: Theory and observe. Oxford Press, Oxford.

Ighosewe, E.F. and Ofor, N.T. (2017). impact of Treasury Single Account (TSA) on Banks Performance in Nigeria: Associate in Nursing wildcat Study. Sahel Analyst: Journal of Management Sciences, 15, 32-49.

IMF monetary Affairs Department (2010). Treasury Single Account: construct, Design, and Implementation. http://ww.imf,org/external/pub/ft/wp/2010/wp10143

Kanu C. (2016). Impact of Treasury Single Account on Liquidity of the Banking Sector, bedrock Journal of Advance analysis (5): 43-52.

Iyer, R., Peydro, J.-L., prosecutor Rocha-Lopes, S. and Schoar, A. (2014). Interbank Liquidity Crunch and additionally the Firm Credit Crunch: proof from the 20072009 Crisis. The Review of economic Studies , 27, 347-372. ttps://doi.org/10.1093/rfs/hht056

Lindblom, C.E. (1959). The Science of "Muddling Through". Public Administration Review, 19, 79-88. https://doi.org/10.2307/973677 
Ndubuaku, V.C., Ohaegbu, O.K. and Nina, N.M. (2017). Impact of Treasury Single Account on the Performance of the Banking Sector in African country. Journal of scientific discipline and Finance, 8, 8-15.

Ocheni, S. (2016). Treasury Single Account: A Catalyst for Public financial Management in African country. The Nation.

Ogbonna, C. and Amuji, H. (2018). Analysis of the Impact of Treasury Single Account on the Performance of Banks in African country. Open Journal of Statistics, 8, 457467. https://doi.org/10.4236/ojs.2018.83029

Onuorah, A.C. (2016). centralized Treasury Single Account (TSA) Deposits and industrial Banks Performance. Journal of Social and Management Sciences, 11, 1-34.

Rossi L. (2016). the simplest way to manage Liquidity head, Liquidity and Investment development, Deutsche Bank.

Tari, V. A., Pwafeyeno, M., \& Minnessi, G. (2016). Treasury Single Account (TSA) Policy in Nigeria: restorative Jonathan's 'Dead' Policy Directives. on-line Journal of Social Sciences analysis, 5, 6-12.

Tayo A. (2015). Accounting tools. http://www.theestle.net/2015/09/05/top-10-banks-inNigeria prime 10 industrial banks in African country.

Uarame, E.I. and Chjioke, E.O. (2015). The Impact of Treasury Single Account on MDAs, Accounting information and Accountability: An abstract Review. Proceedings of the tutorial Conference of Sub-Sahara African, African instructional analysis Publication on New Direction and Uncommon Changes, 2.

Yusuf, M.B. (2016) Effects of Treasury Single Account on Public Finance Management in African country. analysis Journal of Finance and Accounting, 7, 164-170.

Zayol, P.I., Iorlaha, T. and Nege, J.D. (2017) impact of Treasury Single Account on the Liquidity of Deposit money Banks in African country. Journal of scientific discipline and Finance, 8, 55-60.

Appendix A.

TABLE SHOWING THE FEDERAL GOVERNMENT DEPOSIT (FG DEP), CREDIT TO THE PRIVATE SECTOR (CRP), DEPOSIT MOBILISATION (DEP-M) AND LOANS AND ADVANCES (LAD) OF THE COMMERCIAL BANKS FOR THE PERIOD 2003-2018

\begin{tabular}{|c|c|c|c|c|}
\hline DATE & FG Dep (N'Billion) & Dep M (N'Billion) & CrP (N'Billion) & Lad (N'Billion) \\
\hline $\mathbf{2 0 0 3}$ & 73.8 & 530.37 & 343.17 & 508.3 \\
\hline $\mathbf{2 0 0 4}$ & 28.3 & 764.96 & 451.96 & 796.2 \\
\hline $\mathbf{2 0 0 5}$ & 52.6 & 930.49 & 556.01 & 954.6 \\
\hline $\mathbf{2 0 0 6}$ & 79.8 & 1096.54 & 655.74 & 1210.0 \\
\hline $\mathbf{2 0 0 7}$ & 117.2 & 1421.66 & 797.52 & 1519.2 \\
\hline
\end{tabular}




\begin{tabular}{|c|c|c|c|c|}
\hline 2008 & 119.1 & 1838.39 & 1316.96 & 1976.7 \\
\hline 2009 & 134.1 & 2290.62 & 1739.64 & 2524.3 \\
\hline 2010 & 254.5 & 3680.09 & 2693.55 & 4813.5 \\
\hline 2011 & 292.7 & 6941.38 & 4118.17 & 7799.4 \\
\hline 2012 & 451.8 & 9147.42 & 5763.51 & 8912.1 \\
\hline 2013 & 825.6 & 10157.02 & 5954.26 & 7706.4 \\
\hline 2014 & 678.7 & 10660.07 & 6531.91 & 7312.7 \\
\hline 2015 & 1113 & 14649.28 & 8062.10 & 8150.0 \\
\hline 2016 & 2931.60 & 15751.84 & 8606.61 & 10005.6 \\
\hline 2017 & 764.6 & 17129.68 & 11936.90 & 12889.4 \\
\hline 2018 & 53.8 & 18674.15 & 11363.49 & 13086.2 \\
\hline
\end{tabular}

